AGRITECH, Vol. 37, No. 1, Februari 2017, Hal. 22-29

DOI: http://dx.doi.org/10.22146/agritech.17002

ISSN 0216-0455 (Print), ISSN 2527-3825 (Online)

Tersedia online di https://jurnal.ugm.ac.id/agritech/

\title{
Kualitas Mikrobiologis dan Kimiawi Kefir Susu Kambing dengan Penambahan Lactobacillus acidophilus FNCC 0051 dan Tepung Kulit Pisang Kepok (Musa Paradisiaca)
}

\author{
Microbiological and Chemical Quality of Goat Milk Kefir with the Addition of Lactobacillus acidophilus FNCC 0051 \\ and Plantain Peel Flour (Musa paradisiaca)
}

Dwitiya Martharini, I. Indratiningsih

Fakultas Peternakan, Universitas Gadjah Mada, J1. Fauna No.3, Bulaksumur, Yogyakarta 55281, Indonesia

Email: dwitiya.martharini@gmail.com

Submisi: 14 Juli 2015; Penerimaan: 22 April 2016

\begin{abstract}
ABSTRAK
Penelitian ini bertujuan untuk mengetahui pengaruh penambahan tepung kulit pisang dan Lactobacillus acidophilus FNCC 0051 terhadap kualitas mikrobiologis dan kimiawi kefir susu kambing. Kefir dibuat dari susu kambing dengan kefir grain $3 \%(\mathrm{w} / \mathrm{v})$ dan Lactobacillus acidophilus FNCC $0051(0,1$ dan $3 \%(\mathrm{v} / \mathrm{v}))$ serta tepung kulit pisang $(0,1$ dan $2 \%(\mathrm{w} / \mathrm{v}))$. Semua perlakuan diinkubasi pada suhu ruang $\left( \pm 28,5^{\circ} \mathrm{C}\right)$ selama $10 \mathrm{jam}$, hingga $\mathrm{pH}$ turun menjadi 4,2 sampai 4,6. Uji kualitas kefir yang diamati yaitu mikrobiologis (total bakteri asam laktat, viabilitas probiotik, total khamir) dan kimiawi (pH, kadar laktosa, kadar alkohol, kadar lemak, serat pangan). Data hasil uji total bakteri asam laktat, viabilitas probiotik, total khamir, $\mathrm{pH}$, kadar laktosa, kadar alkohol, kadar lemak dianalisis dengan analisis sidik ragam pola faktorial 3x3, dan dilanjutkan dengan Duncan's New Multiple Range Test (DMRT). Data hasil serat pangan dianalisis dengan analisis deskriptif. Hasil penelitian menunjukkan bahwa Lactobacillus acidophilus FNCC 0051 berpengaruh $(p \leq 0,05)$ terhadap penurunan $\mathrm{pH}$, kadar alkohol dan peningkatan bakteri asam laktat serta viabilitas probiotik. Tepung kulit pisang berpengaruh $(p \leq 0,05)$ terhadap peningkatan kadar alkohol dan bakteri asam laktat. Kefir memiliki rerata total bakteri asam laktat yakni $9,51 \log \mathrm{cfu} \mathrm{mL}^{-1}$, viabilitas probiotik $8,65 \log \mathrm{cfu} \mathrm{mL}^{-1}$, total khamir 6,13 log cfu mL $\mathrm{mL}^{-1}, \mathrm{pH} 4,85$, laktosa 3,14\%, kadar alkohol 0,096\%, kadar lemak 5,33\%, dan total serat pangan $10,49 \%$. Hasil penelitian dapat disimpulkan bahwa kualitas kefir semua perlakuan memenuhi standar komposisi kefir menurut standar Codex 234-2003 dan kefir yang terbaik dengan penambahan Lactobacillus acidophilus FNCC 00513 $\%$ dan tepung kulit pisang $1 \%$.
\end{abstract}

Kata kunci: Susu kambing; kefir; Lactobacillus acidophilus FNCC 0051; tepung kulit pisang

\begin{abstract}
This experiment was carried out to investigate the effect of plantain peel flour and Lactobacillus acidophilus FNCC 0051 on the microbiological and chemical quality of goat milk kefir. Kefir was made from goat's milk with $3 \%$ of kefir grain (w/v) and Lactobacillus acidophilus FNCC $0051(0,1$ and $3 \%(\mathrm{v} / \mathrm{v}))$ and plantain peel flour $(0,1$ and $2 \%$ $(\mathrm{w} / \mathrm{v}))$. All treatments were incubated at room temperature $\left( \pm 28.5^{\circ} \mathrm{C}\right)$ for 10 hours, until the $\mathrm{pH}$ dropped to 4.2-4.6. The quality of Kefir was evaluated by microbiological analysis (total of lactic acid bacteria, probiotics viability, total yeast) and chemical analysis ( $\mathrm{pH}$, lactose content, alcohol content, fat content and dietary fiber). The data of total lactic acid bacteria, probiotics viability, total yeast, $\mathrm{pH}$, lactose content, alcohol content, fat content were evaluated by analysis of variance and followed by Duncan's New Multiple Range Test (DMRT). Data of dietary fiber was evaluated by descriptive analysis. The research result showed that the addition of Lactobacillus acidophilus FNCC 0051 had a significant effect $(p \leq 0.05)$ on decreasing $\mathrm{pH}$, alcohol content and increasing total lactic acid bacteria and probiotic
\end{abstract}


viability. Plantain peel flour had significantl effect $(p \leq 0.05)$ on increasing alcohol content and total lactic acid bacteria. Kefir had $9.51 \mathrm{log}$ cfu mL $\mathrm{m}^{-1}$ of lactic acid bacteria total; $8.65 \log$ cfu mL $\mathrm{mL}^{-1}$ of probiotic viability; $6.13 \log \mathrm{cfu} \mathrm{mL} \mathrm{m}^{-1}$ of total yeast; 4.85 of pH; $3.14 \%$ of lactose content; $0.096 \%$ of alcohol content; $5.33 \%$ of fat content; and $10.49 \%$ of dietary fiber. This research concluded that kefir quality for all treatments kefir were complied with Codex Standard 234-2003 while the best treatment was the kefir with the addition of $3 \%$ Lactobacillus acidophilus FNCC 0051 and 1 $\%$ flour banana peel.

Keywords: Goat milk; kefir; Lactobacillus achidophilus FNCC 0051; plantain peel flour

\section{PENDAHULUAN}

Produk pangan yang telah dikembangkan saat ini merupakan pangan yang memadukan antara fungsi gizi dan kesehatan, yang sering disebut pangan fungsional. Salah satu produk pangan fungsional alami yaitu kefir, tetapi di Indonesia belum banyak dikembangkan. Chandan dkk. (2006) menyatakan bahwa kefir merupakan produk yang menghasilkan asam dan alkohol karena bakteri asam laktat dan khamir yang saling berhubungan dalam proses fermentasi. Kualitas kefir bervariasi dipengaruhi oleh jenis dan jumlah mikrobia starter serta bahan awal. Bakteri asam laktat yang lebih dominan bekerja diharapkan dapat menghambat khamir dalam menghasilkan alkohol. Lactobacillus acidophilus merupakan salah satu spesies BAL yang telah banyak dimanfaatkan sebagai probiotik. Kerja probiotik akan optimal bila dibantu dengan adanya prebiotik sebagai makanan dan merangsang pertumbuhannya. Kulit pisang berpotensi sebagai prebiotik.

Indonesia merupakan negara agraris, hampir seluruh wilayah Indonesia menghasilkan tanaman pisang (Musa spp.). Total produksi pisang di wilayah Jawa Tengah mencapai 552.963 ton dan di D.I. Yogyakarta mencapai 43.493 ton (BPS, 2013). Buahnya banyak disukai untuk dikonsumsi, namun hal ini tidak diimbangi dengan pengolahan limbah dari kulit pisang. Pisang menghasilkan limbah kulit pisang sebesar 30 - $40 \mathrm{~g}$ per $100 \mathrm{~g}$ dari berat kulit pisang (Wachirasiri dkk., 2009). Produksi pisang di D.I. Yogyakarta mencapai 43.493 ton maka limbah yang dihasilkan kurang lebih 13.047 - 17.397 ton. Limbah kulit pisang memberikan dampak negatif terhadap lingkungan apabila dibiarkan begitu saja.

Lactobacillus acidophilus adalah organisme probiotik yang mampu menggunakan senyawa prebiotik seperti fructooligosaccharides (FOS), yang bermanfaat dalam sistem pencernaan. FOS merupakan beragam polimer fruktosa yang digunakan secara komersial dalam produk makanan dan suplemen gizi (Barrangou dkk., 2003). Penelitian Kurtoğlu dan Yildiz (2011) menyatakan bahwa FOS dapat dihasilkan dari limbah kulit pisang. Produksi FOS yang berasal dari limbah kulit pisang belum banyak dimanfaatkan. Menurut Kurtoğlu dan Yildiz (2011), kulit pisang mengandung FOS ditemukan hampir $33 \%$ komponen gula dari ekstrak kulit pisang. Hal ini, berpotensi sangat baik untuk dikembangkan mengingat kulit pisang merupakan limbah yang ketersediaanya melimpah. Berdasarkan penjelasan diatas mendorong dilakukan penelitian untuk mengetahui kualitas produk pangan kefir dengan penambahan Lactobacillus acidophilus dan pemanfaatan kulit pisang sebagai prebiotik. Kefir susu kambing merupakan diversifikasi produk susu kambing untuk meningkatkan nilai fungsional susu kambing dengan memanfaatkan kulit pisang. Selain itu dapat mengoptimalisasikan limbah kulit pisang sebagai sumber prebiotik berbasis limbah pangan lokal.

\section{METODE PENELITIAN}

\section{Bahan dan Alat}

Bahan yang digunakan adalah susu kambing Peranakan Ettawa dari kelompok ternak Tegal Agro Turi Sleman Yogyakarta, kefir grain (3 \%) komersial dari Rumah Kefir Yogyakarta, kulit pisang kepok kuning, Lactobacillus acidophilus FNCC 0051, aquades, buffer $\mathrm{pH} 4$, buffer $\mathrm{pH} 7$, $\mathrm{H}_{2} \mathrm{SO}_{4}, \mathrm{NaOH}, \mathrm{Na}_{2} \mathrm{~S}_{2} \mathrm{O}_{3} 0,1 \mathrm{~N}$ Chloramine $\mathrm{T} 0,7 \%$, KI $10 \%$, $\mathrm{HCl} 2 \mathrm{~N}$, amilum $1 \%$, enzim $\alpha$-amilase, pepsin, pankreatin, $\mathrm{KOH}, \mathrm{HCl}, \mathrm{K}_{2} \mathrm{CO}_{3}, \mathrm{~K}_{2} \mathrm{Cr}_{2} \mathrm{O}_{7}$, de Man Rogosa Sharpe (MRS) agar, MRS broth, bile salt, Malt Extract Agar (MEA) dan chlormphenicol. Alat yang digunakan pada penelitian ini meliputi Laminar Air Flow (LAF), blue tip, yellow tip, $\mathrm{pH}$ meter, buret, botol Babcock, sentrifuge, crucible (porosity 2), cawan Petri, driglaski, timbangan analitik, erlenmeyer, botol steril, tabung reaksi, beaker glass, gelas ukur, termometer, corong, labu ukur, oven, inkubator.

\section{Uji Kualitas Susu Pasteurisasi}

Uji kualitas susu pasteurisasi meliputi uji kadar air (Sudarmadji dkk., 1997), kadar protein metode Kjeldahl (Nielsen, 2010), kadar lemak metode Babcock (Nielsen, 2010), kadar laktosa (Sudarmadji dkk., 1997) dan nilai pH (Nielsen, 2010).

\section{Penyiapan Tepung Kulit Pisang}

Kulit pisang diambil pada bagian dalamnya. Bagian dalam kulit pisang tersebut yang digunakan sebagai bahan pembuatan tepung kulit pisang. Kulit pisang bagian dalam 
direndam dalam larutan $100 \%$ perasan jeruk nipis dan 0,5\% asam sitrat untuk mengurangi reaksi pencoklatan enzimatis. Kulit pisang direndam selama 15 menit dan dicuci dengan aquades 2 kali. Proses selanjutnya, kulit pisang dipotong kecil-kecil $\left( \pm 1 \mathrm{~cm}^{2}\right)$ agar mempercepat proses pengeringan. Pengeringan dilakukan dalam oven panas kering dengan suhu $60{ }^{\circ} \mathrm{C}$ selama $12 \mathrm{jam}$, kemudian dilakukan penggilingan dengan menggunakan blender skala 4 selama 2 menit sampai menjadi bubuk dan dilakukan pengayakan dengan saringan berukuran 70 mesh (0,0083 inchi). Tepung kulit pisang yang telah jadi diuji analisis proksimat yakni kadar air, kadar abu, kadar lemak metode Soxhlet, serat kasar (Sudarmadji dkk., 1997) dan kadar protein metode Kjeldahl (Nielsen, 2010).

\section{Penyiapan Kultur Starter Lactobacillus acidophilus FNCC 0051}

Satu ose stok kultur Lactobacillus acidophilus FNCC 0051 pada agar miring ditumbuhkan dalam $10 \mathrm{~mL}$ medium MRS broth dan bile salt 0,15\% (Boke dkk., 2010) steril suhu $121^{\circ} \mathrm{C}$, tekanan 15 psi selama 15 menit. Medium MRS broth yang digunakan telah ditambah dengan jus tomat sebagai sumber fruktosa dengan perbandingan 4:1. Medium yang telah ditanami stok kultur diinkubasi pada suhu $37^{\circ} \mathrm{C}$ selama 24 jam (Nisa dkk., 2008).

Cara pembuatan mother starter yaitu kultur dari medium MRS broth diinokulasikan $5 \%$ ke dalam $50 \mathrm{~mL}$ susu kambing (yang telah ditambah skim $5 \%$ steril dengan tekanan 13 psi selama 10 menit dan diinkubasi pada suhu 37 ${ }^{\circ} \mathrm{C}$ selama 20 jam hingga berbentuk curd. Penambahan skim agar kandungan padatan total sebesar $17 \%$ sampai $20 \%$ (Widodo, 2003).

Cara pembuatan bulk starter yaitu mother starter sebanyak $5 \%$ diinokulasikan ke dalam susu kambing ditambah skim $5 \%$ yang disterilkan dengan volume $50 \mathrm{~mL}$ dan diinkubasi $37^{\circ} \mathrm{C}$ selama 20 jam.

\section{Pembuatan Kefir}

Pembuatan kefir dilakukan dengan metode Chandan dkk. (2006). Toples kaca steril disiapkan, masing-masing diisi $250 \mathrm{~mL}$ susu kambing. Kefir susu kambing dibuat dengan penambahan tepung kulit pisang masing-masing $0 \%, 1 \%$, dan $2 \%(\mathrm{w} / \mathrm{v})$, dipanaskan 80 sampai $85^{\circ} \mathrm{C}$ selama 30 menit, kemudian didinginkan sampai suhu kamar. Sampel susu ditambah $3 \%$ kefir grain (Widodo, 2003) dan diinokulasikan bulk starter Lactobacillus acidophilus FNCC 0051 masingmasing $0 \%, 1 \%$, dan $3 \%(\mathrm{v} / \mathrm{v})$. Susu yang telah diinokulasi diiinkubasi pada suhu ruang $\left( \pm 28,5^{\circ} \mathrm{C}\right)$ selama $10 \mathrm{jam}$, sampai $\mathrm{pH}$ mencapai 4,2 sampai 4,6 dan disaring untuk memisahkan kefir grain.

\section{Uji Mikrobiologis Kefir}

Kualitas mikrobiologis kefir dilakuan uji total BAL, viabilitas probiotik dan total khamir. Metode analisis mikrobiologi menggunakan metode spread-plate count ukuran sampel biasanya terbatas pada $0,1 \mathrm{~mL}$ (Adams dan Moss, 2008) dan untuk menentukan jumlah total BAL dan total khamir, koloni terbentuk dihitung dan dinyatakan dalam $\log$ cfu ml-1 (Nurliyani dkk., 2014). Media uji viabilitas probiotik yaitu MRS agar ditambah bile salt sebanyak 0,15 $\%$ (Boke dkk., 2010), kemudian diinokulasikan sampel pengenceran $10^{-5}, 10^{-6}$ dan $10^{-7}$ masing-masing sebanyak $0,1 \mathrm{~mL}$. Penghitungan total khamir menginokulasikan sampel pengenceran $10^{-3}, 10^{-4}$ dan $10^{-5}$ sebanyak $0,1 \mathrm{~mL}$ ke dalam cawan Petri yang berisi media MEA dan $100 \mu \mathrm{g} \mathrm{mL}$ chloramphenicol (Nurliyani dkk., 2014).

\section{Uji Kimiawi Kefir}

Uji kimiawi kefir meliputi $\mathrm{pH}$ dengan metode Potensiometer (Nielsen, 2010), kadar laktosa (Sudarmadji dkk., 1997), kadar alkohol dengan metode Conway (Yuwono dan Susanto, 1998), kadar lemak metode Babcock (Nielsen, 2010) dan serat pangan metode multienzim (Asp dkk., 1983).

\section{Analisis Data}

Data hasil pengujian total BAL, viabilitas probiotik, total khamir, pH, kadar laktosa, kadar alkohol dan kadar lemak sebanyak tiga kali ulangan dianalisis menggunakan analisis sidik ragam pola faktorial (3x3), dilanjutkan dengan uji Duncan's New Multiple Range Test (DMRT). Data hasil pengujian serat pangan dianalisis dengan analisis deskriptif.

\section{HASIL DAN PEMBAHASAN}

\section{Kualitas Susu Pasteurisasi}

Susu kambing sebelum dibuat produk kefir harus dipasteurisasi untuk membebaskan susu dari mikrobia patogen. Hasil pengujian kualitas susu kambing pasteurisasi dapat dilihat pada Tabel 1.

Tabel 1. Hasil pengujian kualitas susu kambing pasteurisasi

\begin{tabular}{lcc}
\hline \multicolumn{1}{c}{ Komposisi } & Hasil $(\%)$ & Referensi \\
\hline Bahan kering & $14,32 \pm 0,173$ & $13,11 \%{ }^{1)}$ \\
Protein & $4,79 \pm 0,168$ & $4,72 \pm 0,195 \%^{2)}$ \\
Lemak & $3,45 \pm 0,188$ & $3,43 \pm 0,152 \%^{2)}$ \\
Laktosa & $4,17 \pm 0,103$ & $4,30 \pm 0,190 \%^{2)}$ \\
\hline
\end{tabular}

Keterangan: ${ }^{1)}$ Indratiningsih dkk. (2008)

2) Purnomo dan Muslimin (2012) 
Hasil pengujian diketahui bahwa susu pasteurisasi yang digunakan tidak jauh berbeda dengan hasil penelitian Indratiningsih dkk. (2008) dan Purnomo dan Muslimin (2012). Widodo (2003) menyatakan bahwa beberapa susu dengan kandungan padatan total (total solid) tinggi diduga mempunyai keasaman yang lebih tinggi daripada kondisi standar. Secara umum, penurunan keasaman menandakan kecenderungan mengarah pada penurunan persentase lemak, padatan total, padatan non lemak, kasein, dan laktosa.

\section{Kualitas Tepung Kulit Pisang}

Tepung kulit pisang ditambahkan dalam pembuatan kefir sebagai sumber FOS. Hasil pengujian tepung kulit pisang menunjukkan bahwa kadar air sebesar 13,63\%, lebih tinggi dibandingkan dengan penelitian Alyani (2013) yang menggunakan kulit pisang dari peringkat 7 kematangan yakni $11,29 \%$. Kadar protein tepung kulit pisang yang digunakan pada penelitian yakni $8,39 \%$, mendekati hasil penelitian Wachirasiri dkk. (2009) yakni 8,6 $\pm 0,1 \%$. Uji kadar lemak penelitian sebesar $15,13 \%$ lebih besar dibandingkan hasil penelitian Wachirasiri dkk. (2009) dengan kadar lemak sebesar 13,1 $\pm 0,2 \%$. Serat kasar berdasarkan hasil penelitian diperoleh 9,08 \%, sedangkan hasil penelitian Alyani (2013) serat kasar yang diperoleh sebesar 10,92\%. Karbohidrat sebesar 56,61 \% lebih rendah dari hasil Alyani (2013) yakni $59,91 \%$. Palupi (2012) menyatakan bahwa pembuatan tepung pisang dengan jenis pisang yang berbeda akan memberikan pengaruh nyata pada kadar air, protein, lemak, abu, serat kasar, pati, rendemen, warna, serta organoleptik warna, tekstur dan aroma.

\section{Kualitas Mikrobiologis}

\section{Total BAL}

Bakteri Asam Laktat adalah agen utama fermentasi, BAL memanfaatkan laktosa menghasilkan asam laktat (Chandan dkk., 2006). Data hasil pengujian BAL kefir dengan penambahan tepung kulit pisang dan Lactobacillus acidophilus FNCC 0051 dengan konsentrasi yang berbeda dapat dilihat pada Tabel 2.

Penambahan Lactobacillus acidophilus FNCC 0051 berpengaruh $(p \leq 0,05)$ terhadap total BAL kefir, sedangkan perlakuan dengan penambahan tepung kulit pisang memberikan pengaruh $(p \leq 0,05)$ terhadap total BAL kefir. Aktivitas bakteri asam laktat meningkat dengan adanya tepung kulit pisang. Penelitian Barrangou dkk. (2003) menunjukkan adanya peran dari fruktosidase dalam hidrolisis FOS oleh Lactobacillus acidophilus. Menurut Kurtoğlu dan Yildiz (2011), kulit pisang mengandung fructooligosaccharides ditemukan hampir $33 \%$ komponen gula dari ekstrak kulit pisang. Nuraida dkk. (2011) menyatakan bahwa
Tabel 2. Hasil total bakteri asam laktat $\left(\log \mathrm{cfu} \mathrm{m}^{-1}\right)$ kefir dengan penambahan tepung kulit pisang dan Lactobacillus acidophilus FNCC 0051

\begin{tabular}{|c|c|c|c|c|}
\hline \multirow{2}{*}{$\begin{array}{l}\text { Tepung kulit } \\
\text { pisang (\%) }\end{array}$} & \multicolumn{3}{|c|}{ Lactobacillus acidophilus FNCC 0051 (\%) } & \multirow{2}{*}{ Rerata } \\
\hline & 0 & 1 & 3 & \\
\hline 0 & $9,49 \pm 0,40$ & $9,69 \pm 0,59$ & $9,26 \pm 0,09$ & $40^{\mathrm{x}}$ \\
\hline 1 & $9,34 \pm 0,09$ & $9,29 \pm 0,15$ & $9,13 \pm 0,17$ & $9,25 \pm 0,15^{\mathrm{x}}$ \\
\hline 2 & $9,35 \pm 0,12$ & $10,25 \pm 0,25$ & $9,77 \pm 0,28$ & $9,79 \pm 0,44^{y}$ \\
\hline Rerata & $9,39 \pm 0,22^{\mathrm{a}}$ & $9,74 \pm 0,53^{\mathrm{b}}$ & $9,39 \pm 0,34^{\mathrm{a}}$ & $9,51 \pm 0,41$ \\
\hline
\end{tabular}

Keterangan: ${ }^{\text {a,b }}$ superscript yang berbeda pada baris yang sama menunjukkan perbedaan $(p \leq 0,05)$

${ }^{\mathrm{x}, \mathrm{y}}$ superscript yang berbeda pada kolom yang sama menunjukkan perbedaan $(p \leq 0,05)$

FOS dapat dipecah oleh enzim (3-fruktosidase) menghasilkan molekul glukosa dan fruktosa. Enzim ini merupakan enzim ekstraseluler yang bersifat induktif. Jadi enzim hanya akan diproduksi ketika substrat yang sesuai yaitu FOS ada di lingkungan pertumbuhan BAL.

Farnworth (2005) menyatakan bahwa pada kefir grain ditemukan Lactococci 7,37 log cfu $\mathrm{g}^{-1}$ dan Lactobacilli 8,94 $\log \mathrm{cfu}^{-1}$,sedangkan minuman kefir terdapat Lactococci 8,54 $\log$ cfu g $^{-1}$ dan Lactobacilli 7,45 log cfu $\mathrm{g}^{-1}$. Hasil penelitian Nurliyani dkk. (2014) diperoleh total BAL kefir kombinasi susu kambing dan susu kedelai sebesar 6,86 sampai 7,72 $\log$ cfu $\mathrm{mL}^{-1}$. Berdasarkan Codex Standard susu fermentasi (2003) kefir yang dikonsumsi minimal mengandung BAL yakni minimal $7 \log$ cfu $\mathrm{mL}^{-1}$.

\section{Viabilitas probiotik}

Hasil pengujian viabilitas probiotik kefir dengan penambahan tepung kulit pisang dan Lactobacillus acidophilus FNCC 0051 dapat dilihat pada Tabel 3.

Penambahan Lactobacillus acidophilus FNCC 0051 berpengaruh $(p \leq 0,05)$ terhadap viabilitas probiotik kefir sedangkan perlakuan dengan penambahan tepung kulit pisang berpengaruh tidak nyata terhadap viabilitas probiotik

Tabel 3. Total probiotik (log cfu $\mathrm{mL}^{-1}$ ) kefir dengan penambahan tepung kulit pisang dan Lactobacillus acidophilus FNCC 0051

\begin{tabular}{|c|c|c|c|c|}
\hline \multirow{2}{*}{$\begin{array}{l}\text { Tepung kulit } \\
\text { pisang }(\%)\end{array}$} & \multicolumn{3}{|c|}{ Lactobacillus acidophilus FNCC 0051(\%) } & \multirow{2}{*}{ Rerata $^{n s}$} \\
\hline & 0 & 1 & 3 & \\
\hline 0 & $8,45 \pm 0,25$ & $8,76 \pm 0,90$ & $9,03 \pm 0,49$ & $8,74 \pm 0,58$ \\
\hline 1 & $8,16 \pm 0,93$ & $8,50 \pm 0,69$ & $8,99 \pm 0,41$ & $8,55 \pm 0,71$ \\
\hline 2 & $8,38 \pm 0,10$ & $8,33 \pm 0,10$ & $9,26 \pm 0,15$ & $8,66 \pm 0,46$ \\
\hline Rerata & $8,33 \pm 0,50^{\mathrm{a}}$ & $8,53 \pm 0,60^{\mathrm{a}}$ & $9,09 \pm 0,35^{\mathrm{b}}$ & $8,65 \pm 0,58$ \\
\hline
\end{tabular}

Keterangan: ${ }^{a, b}$ superscript yang berbeda pada baris yang sama menunjukkan perbedaan $(p \leq 0,05)$ ${ }^{\mathrm{ns}}$ not significant 
kefir. Organisme probiotik harus ada dalam makanan 6 log cfu $\mathrm{mL}^{-1}$, atau konsumsi harian sebaiknya sekitar $9 \log \mathrm{cfu}$ $\mathrm{mL}^{-1}$. Viabilitas juga tergantung pada ketersediaan nutrisi, promotor pertumbuhan, dan inhibitor, konsentrasi gula, tingkat inokulasi, dan waktu fermentasi (Tamime, 2005).

\section{Total khamir}

Kefir diperoleh melalui proses fermentasi oleh BAL dan khamir/ragi yang hidup bersimbiosis dan tumbuh dalam perbandingan yang seimbang di dalam kefir grain. Khamir berperan dalam menghasilkan $\mathrm{CO}_{2}$ dan sedikit alkohol (Usmiati, 2007). Hasil pengujian total khamir kefir dengan penambahan tepung kulit pisang dan Lactobacillus acidophilus FNCC 0051 dapat dilihat pada Tabel 4.

Tabel 4. Total khamir (log cfu ml $\left.\mathrm{l}^{-1}\right)$ kefir dengan penambahan tepung kulit pisang dan Lactobacillus acidophilus FNCC 0051

\begin{tabular}{|c|c|c|c|c|}
\hline \multirow{2}{*}{$\begin{array}{c}\text { Tepung kulit } \\
\text { pisang }(\%)\end{array}$} & \multicolumn{3}{|c|}{ Lactobacillus acidophilus FNCC 0051 (\%) } & \multirow{2}{*}{ Rerata $^{n s}$} \\
\hline & 0 & 1 & 3 & \\
\hline 0 & $5,96 \pm 0,36$ & $6,23 \pm 0,15$ & $6,30 \pm 0,39$ & $6,17 \pm 0,32$ \\
\hline 1 & $6,00 \pm 0,25$ & $6,10 \pm 0,12$ & $6,15 \pm 0,18$ & $6,09 \pm 0,18$ \\
\hline 2 & $6,35 \pm 1,06$ & $6,02 \pm 0,25$ & $6,02 \pm 0,18$ & $6,13 \pm 0,58$ \\
\hline Rerata $^{n s}$ & $6,10 \pm 0,60$ & $6,12 \pm 0,18$ & $6,16 \pm 0,26$ & $6,13 \pm 0,38$ \\
\hline
\end{tabular}

Keterangan $:{ }^{n s}$ not significant

Rerata total khamir dengan penambahan Lactobacillus acidophilus FNCC 0051 berkisar antara 6,10 hingga 6,16 log cfu $\mathrm{mL}^{-1}$. Rerata total khamir dengan penambahan tepung kulit pisang berkisar antara 6,09 hingga 6,17 log cfu $\mathrm{mL}^{-1}$. Hasil penelitian Nurliyani dkk. (2014) diperoleh khamir kefir kombinasi susu kambing dan susu kedelai masing-masing sebesar 4,99 hingga 5,81 log $\mathrm{cfu} \mathrm{mL}^{-1}$. Hasil penelitian Farnworth (2005) menyatakan bahwa khamir dalam minuman kefir ditemukan 5,24 log cfu g-1.

\section{Kualitas Kimiawi}

\section{pH}

Hasil pengujian nilai $\mathrm{pH}$ kefir dengan penambahan tepung kulit pisang dan Lactobacillus acidophilus FNCC 0051 yang berbeda dapat dilihat pada Tabel 5 .

Kefir dengan penambahan tepung kulit pisang memberikan pengaruh tidak nyata terhadap nilai $\mathrm{pH}$ kefir, tetapi perlakuan dengan penambahan Lactobacillus acidophilus FNCC 0051 berpengaruh $(p \leq 0,05)$ terhadap nilai $\mathrm{pH}$ kefir. Umumnya $\mathrm{pH}$ kefir antara 4,2 sampai 4,6 (Farnworth, 2008). Hasil penelitian Umam dkk. (2012) diperoleh nilai $\mathrm{pH}$ minuman sinbiotik buah pisang kepok dengan starter Lactobacillus acidophillus IFO 13951 tanpa
Tabel 5. Nilai pH kefir dengan penambahan tepung kulit pisang dan Lactobacillus acidophilus FNCC 0051

\begin{tabular}{|c|c|c|c|c|}
\hline \multirow{2}{*}{$\begin{array}{c}\text { Tepung kulit } \\
\text { pisang (\%) }\end{array}$} & \multicolumn{3}{|c|}{ Lactobacillus acidophilus FNCC 0051 (\%) } & \multirow{2}{*}{ Rerata $^{n s}$} \\
\hline & 0 & 1 & 3 & \\
\hline 0 & $5,28 \pm 0,56$ & $4,98 \pm 0,16$ & $4,76 \pm 0,30$ & $5,01 \pm 0,40$ \\
\hline 1 & $5,01 \pm 0,62$ & $4,65 \pm 0,23$ & $4,42 \pm 0,35$ & $4,69 \pm 0,46$ \\
\hline 2 & $5,18 \pm 0,44$ & $4,79 \pm 0,27$ & $4,56 \pm 0,37$ & $4,84 \pm 0,42$ \\
\hline Rerata & $5,16 \pm 0,49^{b}$ & $4,81 \pm 0,24^{\mathrm{ab}}$ & $4,58 \pm 0,33^{\mathrm{a}}$ & $4,85 \pm 0,43$ \\
\hline
\end{tabular}

Keterangan: ${ }^{\mathrm{a}, \mathrm{b}}$ superscript yang berbeda pada baris yang sama menunjukan perbedaan $(\mathrm{P} \leq 0,05)$ ${ }^{n s}$ not significant

skim dan skim 7,5 \% masing-masing yakni 4,31 dan 3,44. Umumnya $\mathrm{pH}$ kefir antara 4,2 sampai 4,6 (Farnworth, 2008). Semakin tinggi persentase penambahan Lactobacillus acidophilus FNCC 0051 maka nilai pH kefir semakin rendah. Hal ini disebabkan karena Lactobacillus acidophilus sebagai BAL mengubah laktosa menjadi asam laktat membuat pH menjadi turun. Hasil penelitian Yelnetty dkk. (2014), yoghurt susu kambing dengan penambahan $1 \%$ pati pisang lokal memiliki karakteristik yang lebih baik diantara semua perlakuan. Penambahan pati pisang lokal $1 \%$ pada penelitian tersebut memperoleh viabilitas bakteri asam laktat tertinggi dan $\mathrm{pH}$ terendah.

Kefir dengan penambahan tepung kulit pisang $2 \%$ mengalami penurunan $\mathrm{pH}$ dari kontrol, tetapi penurunan $\mathrm{pH}$ pada penambahan tepung kulit pisang $2 \%$ lebih lambat dibandingkan penambahan tepung kulit pisang $1 \%$. Substrat mempengaruhi kemampuan bakteri probiotik dalam memfermentasi substrat untuk pertumbuhannya. Semakin kompleks senyawa maka lebih membutuhkan waktu yang lama untuk dihidrolisis. Menurut Laily dkk. (2014), penurunan pH terjadi karena adanya aktivitas BAL dalam menghasilkan energi melalui proses fermentasi dengan memecah subtrat menjadi komponen yang lebih sederhana. Pembentukan energi ditunjukkan untuk pembentukan sel. Selain dihasilkan energi pemecahan laktosa juga menghasilkan asam laktat pembentukan asam tersebut yang kemudian terakumulasi menyebabkan turunnya nilai $\mathrm{pH}$.

\section{Kadar laktosa}

Komponen karbohidrat utama dalam susu adalah laktosa. Laktosa yang terdapat pada susu didegradasi menjadi asam laktat selama proses fermentasi (Farnworth, 2008). Hasil pengujian kadar laktosa kefir dengan penambahan tepung kulit pisang dan Lactobacillus acidophilus FNCC 0051 yang berbeda dapat dilihat pada Tabel 6 . 
Tabel 6. Kadar laktosa (\%) kefir dengan penambahan tepung kulit pisang dan Lactobacillus acidophilus FNCC 0051

\begin{tabular}{|c|c|c|c|c|}
\hline \multirow{2}{*}{$\begin{array}{l}\text { Tepung kulit } \\
\text { pisang (\%) }\end{array}$} & \multicolumn{3}{|c|}{ Lactobacillus acidophilus FNCC 0051 (\%) } & \multirow{2}{*}{ Rerata $^{n s}$} \\
\hline & 0 & 1 & 3 & \\
\hline 0 & $3,36 \pm 0,96$ & $2,89 \pm 1,45$ & $3,27 \pm 0,75$ & $3,17 \pm 0,97$ \\
\hline 1 & $2,80 \pm 1,53$ & $3,38 \pm 0,92$ & $3,42 \pm 0,41$ & $3,20 \pm 0,96$ \\
\hline 2 & $2,79 \pm 1,38$ & $3,09 \pm 0,93$ & $3,27 \pm 0,38$ & $3,05 \pm 0,88$ \\
\hline Rerata $^{n s}$ & $2,98 \pm 1,17$ & $3,12 \pm 0,99$ & $3,32 \pm 0,48$ & $3,14 \pm 0,90$ \\
\hline
\end{tabular}

Keterangan: ${ }^{n s}$ not significant

Penambahan Lactobacillus acidophilus FNCC 0051 dan penambahan tepung kulit pisang tidak berpengaruh terhadap kadar laktosa kefir. Hasil penelitian Nurliyani (1994), kadar laktosa kefir dari susu kambing dengan kefir grain $3 \%$ yakni $3,68 \%$. Chandan dkk. (2006) berpendapat bahwa selama fermentasi, bakteri asam laktat mengkonversi $20 \%$ sampai $30 \%$ dari laktosa menjadi asam laktat.

\section{Kadar alkohol}

Hasil pengujian kadar alkohol kefir dengan penambahan tepung kulit pisang dan Lactobacillus acidophilus FNCC 0051 yang berbeda dapat dilihat pada Tabel 7 .

Perlakuan dengan penambahan tepung kulit pisang memberikan pengaruh nyata terhadap kadar alkohol. Kefir memproduksi alkohol sebesar 0,3 sampai $1 \%$ (Chandan dkk., 2006), sedangkan batas normal berdasarkan pernyataan Adams dan Moss (2008) bahwa kandungan alkohol yang memiliki kefir bervariasi antara $0,01 \%$ dan $1 \%$. Menurut Farnworth (2008), kadar alkohol pada kefir dipengaruhi oleh metabolisme khamir dan bakteri heterofermentatif yang menghasilkan etanol. Berdasarkan penelitian $\mathrm{Oh}$ dkk. (2013) menyatakan bahwa kadar etanol dari kefir dengan penambahan oligosakarida yang berbeda ditemukan meningkat secara bertahap selama fermentasi. Kadar etanol

Tabel 7. Hasil kadar alkohol (\%) dengan penambahan tepung kulit pisang dan Lactobacillus acidophilus FNCC 0051

\begin{tabular}{ccccc}
\hline \multirow{2}{*}{$\begin{array}{c}\text { Tepung kulit } \\
\text { pisang (\%) }\end{array}$} & \multicolumn{2}{c}{ Lactobacillus acidophilus FNCC 0051(\%) } & Rerata \\
\cline { 2 - 4 } & 0 & 1 & 3 & \\
\hline 0 & $0,076 \pm 0,03$ & $0,059 \pm 0,01$ & $0,059 \pm 0,01$ & $0,065 \pm 0,02^{\mathrm{x}}$ \\
1 & $0,179 \pm 0,07$ & $0,093 \pm 0,05$ & $0,064 \pm 0,02$ & $0,111 \pm 0,07^{\mathrm{y}}$ \\
2 & $0,161 \pm 0,06$ & $0,096 \pm 0,04$ & $0,074 \pm 0,01$ & $0,110 \pm 0,05^{\mathrm{y}}$ \\
Rerata & $0,139 \pm 0,07^{\mathrm{b}}$ & $0,083 \pm 0,04^{\mathrm{a}}$ & $0,066 \pm 0,02^{\mathrm{a}}$ & $0,096 \pm 0,05$
\end{tabular}

Keterangan: ${ }^{\mathrm{a}, \mathrm{b}}$ superscript yang berbeda pada baris yang sama menunjukkan perbedaan $(p \leq 0,01)$

${ }^{\mathrm{x} . \mathrm{y}}$ superscript yang berbeda pada kolom yang sama menunjukkan perbedaan $(p \leq 0,05)$ dari sampel penambahan fructo-oligosaccharides (FOS) secara signifikan lebih tinggi dibandingkan oligosakarida komersial seperti maltotriose, galactooligosaccharide (GOS), dan isomaltooligosaccharide (IMO).

\section{Kadar lemak}

Penambahan Lactobacillus acidophilus FNCC 0051 tidak berpengaruh terhadap kadar lemak kefir. Rerata kadar lemak dengan Lactobacillus acidophilus FNCC $00510 \%, 1$ $\%$ dan $3 \%$ berturut-turut yakni 5,70 $\pm 1,32 \%, 5,26 \pm 0,35$ $\%$ dan 5,04 $\pm 1,83 \%$. Berdasarkan hasil penelitian, semakin besar persentase penambahan Lactobacillus acidophilus FNCC 0051 maka kadar lemak akan semakin rendah. Sawitri (1996) menyatakan perkembangbiakan BAL akan semakin meningkat dan menyebabkan enzim lipase yang dihasilkan semakin banyak sehingga lemak yang terhidrolisis juga semakin banyak, mengakibatkan turunnya kadar lemak. Perlakuan dengan penambahan tepung kulit pisang memberikan pengaruh tidak nyata terhadap kadar lemak kefir. Rerata kadar lemak dengan tepung kulit pisang $0 \%, 1 \%$ dan $2 \%$ berturut-turut yakni $4,98 \pm 1,44 \%, 5,37 \pm 0,59 \%$, dan $5,66 \pm 1,67 \%$. Kadar lemak kefir menurut Codex Standar susu fermentasi (2003) yakni kurang dari $10 \%$.

\section{Serat pangan}

Kandungan serat berperan sebagai pangan kesehatan salah satunya serat pangan. Data hasil pengujian serat pangan kefir dengan penambahan tepung kulit pisang dan Lactobacillus acidophilus FNCC 0051 yang berbeda dapat dilihat pada Tabel 8 .

Fructo-oligosaccharides merupakan serat pangan yang tergolong dalam serat larut air. Penentuan kadar serat larut air lebih sensitif jika menggunakan analisis dengan

Tabel 8. Serat pangan kefir dengan penambahan tepung kulit pisang dan Lactobacillus acidophilus FNCC 0051

\begin{tabular}{|c|c|c|c|c|c|c|c|}
\hline \multicolumn{2}{|c|}{ Perlakuan } & \multirow{2}{*}{\multicolumn{2}{|c|}{ Serat tak larut }} & \multirow{2}{*}{\multicolumn{2}{|c|}{ Serat larut }} & \multirow{2}{*}{\multicolumn{2}{|c|}{ Serat total }} \\
\hline \multirow{2}{*}{$\begin{array}{l}\text { Tepung } \\
\text { kulit pisang }\end{array}$} & \multirow{2}{*}{$\begin{array}{c}\text { Lactobacillus } \\
\text { acidophilus } \\
\text { FNCC } 0051\end{array}$} & & & & & & \\
\hline & & $\%$ wb & $\% \mathrm{db}$ & $\%$ wb & $\% \mathrm{db}$ & $\%$ wb & $\% \mathrm{db}$ \\
\hline \multirow[t]{3}{*}{$0 \%$} & $0 \%$ & 2,73 & 2,88 & 6,83 & 7,20 & 9,56 & 10,07 \\
\hline & $1 \%$ & 4,45 & 4,75 & 5,58 & 5,96 & 10,02 & 10,71 \\
\hline & $3 \%$ & 3,01 & 3,23 & 7,03 & 7,55 & 10,04 & 10,78 \\
\hline \multirow[t]{3}{*}{$1 \%$} & $0 \%$ & 4,70 & 4,95 & 7,01 & 7,38 & 11,71 & 12,34 \\
\hline & $1 \%$ & 2,79 & 2,92 & 5,60 & 5,87 & 8,38 & 8,79 \\
\hline & $3 \%$ & 4,83 & 5,03 & 6,30 & 6,55 & 11,13 & 11,58 \\
\hline \multirow[t]{3}{*}{$2 \%$} & $0 \%$ & 4,13 & 4,42 & 5,50 & 5,88 & 9,63 & 10,30 \\
\hline & $1 \%$ & 2,38 & 2,47 & 4,93 & 5,13 & 7,31 & 7,60 \\
\hline & $3 \%$ & 5,91 & 6,20 & 5,75 & 6,03 & 11,67 & 12,23 \\
\hline Rerata & & 3,88 & 4,09 & 6,06 & 6,40 & 9,94 & 10,49 \\
\hline
\end{tabular}


prinsip enzimatis (McCleary dkk., 2011). Berdasarkan hasil penelitian diperoleh data serat larut kefir dalam bahan kering sebesar 5,13\% sampai 7,55\% dan rerata serat larut yakni $6,39 \%$. Serat tak larut kefir dalam bahan kering sebesar 2,47 $\%$ sampai 6,19\% dan rerata serat tak larut yakni 4,09\%. Total serat pangan kefir yakni 7,60\% sampai $12,34 \%$ dan rerata total serat dalam bahan kering yakni 10,49\%. Hasil penelitian Karlin dan Rahayuni (2014) tentang potensi yogurt tanpa lemak dengan penambahan tepung pisang dan tepung gembili sebagai alternatif menurunkan kolesterol, yoghurt dengan penambahan tepung pisang sebanyak 16,5 g mengandung $1 \%$ FOS memiliki kadar serat dengan metode gravimetri sebesar 0,03\%. Wachirasiri dkk. (2009) menyatakan bahwa tepung kulit pisang yang dibuat dengan metode dry milling memiliki total serat pangan sebesar $83,00 \%$ dan serat larut sebesar $12,48 \%$.

\section{KESIMPULAN}

Hasil penelitian menunjukkan bahwa penambahan Lactobacillus acidophilus FNCC 0051 dapat meningkatkan total bakteri asam laktat dan viabilitas probiotik, serta menurunkan nilai $\mathrm{pH}$ dan kadar alkohol. Penambahan tepung kulit pisang mampu menaikan kadar alkohol. Kualitas kefir semua perlakuan memenuhi standar komposisi kefir menurut Codex Stan 234-2003 dan kefir dengan kualitas yang terbaik yakni penambahan Lactobacillus acidophilus FNCC 00513 $\%$ dan tepung kulit pisang $1 \%$.

\section{UCAPAN TERIMA KASIH}

Penulis menyampaikan terima kasih kepada PT. Indofood CBP Sukses Makmur Tbk., yang telah mensponsori penelitian melalui Program Indofood Riset Nugraha $2014 / 2015$.

\section{DAFTAR PUSTAKA}

Adams, M.R dan Moss, M.O. (2008). Food Microbiology. $3^{\text {rd }}$ Edn. The Royal Society of Chemistry Publishing. UK.

Alyani, Z. (2013). Utilisation of banana peel (Musa paradisiaca) and chicken as the ingredients in dried yellow noodle (Abstr.). Degree of Bachelor of Science (Hons.) Science and Food Technology Thesis, Universiti Teknologi MARA.

Asp, N.G., Johansson, C.G., Halmer, H. dan Siljestrom, M. (1983). Rapid enzimatic assay of insoluble and soluble dietary fiber. Journal of Agricultural and Food Chemistry 31: 476-482.
Badan Pusat Statistik (2013). Produksi buah-buahan menurut provinsi (Ton), 2013. http://www.bps.go.id. [11 April 2014].

Barrangou, R., Altermann, E., Hutkins, R., Cano, R., dan Klaenhammer, T.R. (2003). Functional and comparative genomic analyses of an operon involved in fructooligosaccharide utilization by Lactobacillus acidophilus. Proceeding of the National Academy Sciences. USA, 100: 8957-8962.

Boke, H., Aslim, B. dan Alp, G. (2010). The role of resistance to bile salts and acid tolerance of exopolysaccharides (epss) produced by yogurt starter bacteria. Archives of Biological Science Belgrade 62: 323-328.

Chandan, R.C., White, C.H., Kilara, A. dan Hui, Y.H. (2006). Manufacturing Yogurt and Fermented Milks. $1^{\text {st }}$ edn. Balckwell Publishing. UK.

Codex Alimentarius Commission (2003). Codex Standard for Fermented Milk: Codex STAN 243. FAO/WHO Food Standards.

Farnworth, E.R. (2005). Kefir - a complex probiotic. Food Science and Technology Bulletin: Functional Foods 2: $1-17$.

Farnworth, E.R. (2008). Handbook of Fermented Functional Foods, $2^{\text {nd }}$ Edn. CRC Press. New York.

Indratiningsih, Djojowidagdo, S., Bachruddin, Z. dan Widyabroto, B. P. (2008). Pengaruh pemanasan terhadap profil asam lemak dan Conjugated Linoleic Acid (CLA) pada susu kambing. Agritek Edisi Hari Pendidikan Nasional 17: 144-149.

Karlin, R. dan Rahayuni, A. (2014). Potensi yogurt tanpa lemak dengan penambahan tepung pisang dan tepung gembili sebagai alternatif menurunkan kolesterol. Journal of Nutrition College 3: 16-25.

Kurtoğlu, G. dan Yildiz, S. (2011). Extraction of fructooligosaccaride components from banana peels. Gazi University Journal of Science 24: 877-882.

McCleary, B.V., DeVries, J.W., Rader, J.I., Cohen, G., Prosky, L., Mugford, D.C., Champ, M. dan Okuma, K. (2012). Collaborative study report: Determination of insoluble, soluble, and total dietary fiber (codex definition) by an enzymatic-gravimetric method and liquid chromatography. AACC International Report2011 56: 238-247.

Nielsen, S.S. (2010). Food Analysis. $4^{\text {th }}$ edn. Springer New York Dordrecht Heidelberg London. 
Nisa, F.C., Kusnadi, J. dan Chrisnasari, R. (2008). Viabilitas dan deteksi subletal bakteri probiotik pada susu kedelai fermentasi instan metode pengeringan beku (kajian jenis isolat dan konsentrasi sukrosa sebagai krioprotektan). Jurnal Teknologi Pertanian 9: 40-51.

Nuraida, L., Mardiana, N.R., Faridah, D.N. dan Hana (2011). Metabolisme prebiotik oleh kandidat probiotik isolate ASI sebagai dasar pengembangan produk sinbiotik. Jurnal Teknologi dan Industri Pangan 22: 156-163.

Nurliyani (1994). Kualitas kefir yang dibuat dari susu sapi dan susu kambing. Buletin Peternakan 18: 55-61.

Nurliyani, Harmayani, E. dan Sunarti (2014). Microbiologi quality, fatty acid and amino acid profiles of kefir produced from combination of goat and soy milk. Pakistan Journal of Nutrition 13: 107-115.

Oh, N.S., Lee, H.A., Myung, J.H., Lee, J.Y. dan Joung, J.Y. (2013). Effect of different commercial oligosaccharides on the fermentation properties in kefir during fermentation. Korean Journal for Food Science of Animal Resource 33: 325-330.

Palupi, H.T. (2012). Pengaruh jenis pisang dan bahan perendam terhadap karakteristik tepung pisang (Musa spp.). Jurnal Teknologi Pangan 4: 102-120.

Purnomo, H dan Muslimin, L.D. (2012). Chemical characteristics of pasteurised goat milk and goat milk kefir prepared using different amount of indonesian kefir grains and incubation times. International Food Research Journal 19: 791-794.

Sawitri, M.E. (1996). Pengaruh Konsentrasi Kefir Grains Terhadap Kualitas Kefir. Laporan Penelitian Fakultas Peternakan. Universitas Brawijaya.
Sudarmadji, S., Haryono, B. dan Suhardi (1997). Prosedur Analisa Untuk Bahan Makanan Dan Pertanian. Penerbit angkasa. Bandung.

Tamime, A. Y. (2005). Probiotic Dairy Products. Blackwell Publishing. Dairy Science and Technology Consultant, Ayr. UK.

Umam, F.M, Utami, R. dan Widowat, E. (2012). Kajian karakteristik minuman sinbiotik pisang kepok (Musa paradisiaca forma typical) dengan menggunakan starter Lactobacillus acidophilus IFO 13951 dan Bifidobacterium longum ATCC 15707. Jurnal Teknosains Pangan 1: 2-11.

Usmiati, S. (2007). Kefir, Susu fermentasi yang menyegarkan dan menyehatkan. Badan Litbang Pertanian. Warta Penelitian dan Pengembangan Pertanian 29: 12-14.

Wachirasiri, P., Julakarangka, S. dan Wanlapa, S. (2009). The effects of banana peel preparations on the properties of banana peel dietary fibre concentrate. Songklanakarin Journal of Science and Technology 31: 605-611.

Widodo (2003). Bioteknologi Industri Susu. Cetakan Ke-1. Lacticia Press, Yogyakarta.

Yelnetty, A., Hadju, R. Tamasoleng, M. dan Sakul, S. (2014). Characteristic of local banana starch as prebiotic and effect addition of starch on physico chemical properties of goat milk yoghurt (Abstr.). Proceedings of the $16^{\text {th }}$ AAAP Animal Science Congress 2: 339.

Yuwono, S. dan Susanto, T. (1998). Pengujian Fisik Pangan. UNESA University Press. Surabaya. 